\title{
PRECARIOUS LOCATIONS: FEMINIST CO-OPTATION AND STRATEGIES OF RESISTANCE IN THE NEOLIBERAL AGE
}

\author{
ALEXANDRA ANA
}

\begin{abstract}
As women gained access to influence politics through official channels, the social justice concerns of feminist activists started to be pursued in Romania through institutionalized forms of political intervention. The institutionalization and professionalization of the feminist movement were widely associated with feminist and women NGOs collaborating with governmental gender equality bodies to advance movement goals and achieve policy success. While some scholars insisted on the benefits of infusing feminist ideas and practices within the state, others considered that NGOization made the feminist movement susceptible of cooptation contributing to its demobilization and depoliticization. The concept of co-optation reflects the dilemmas faced by contemporary feminist movements regarding the displacement of feminist goals and concerns that might be adapted to other priorities and agendas sometimes adverse and conflicting with the original aims - once they become part of the official political channels of decision-making. The resource dependency of feminist NGOs and groups on state or private funds is also associated with the co-optation of movement organizations.

With this in mind, how does one build on critical analyses around the concept of co-optation without disbanding the actions and efforts of feminist activists and NGOs as legitimating the policy agendas of state or private donors? This study aims, first, to explain, the tensions engendered by co-optation and the insider/outsider dilemma facing the contemporary feminist movement and, second, to explore the strategies developed by the feminist movement to resist or govern co-optation. In order to explore the process of co-optation, especially the tensions and strategies of resistance engendered by it, the paper uses the NGOization body of literature and provides empirical evidence from research on the Romanian feminist movement.
\end{abstract}

Keywords: Cooptation, institutionalization, NGOization, feminist movement, resource dependency 


\section{Introduction}

After the fall of state-socialist regimes in Central and Eastern Europe (CEE), social movements were described as transactional, professionalized and lacking potential for broad political mobilization (Cîrstocea 2010; Petrova, Tarrow 2007). The financial dependency on foreign resources (Gal and Kligman 2003) was an element widely present in the NGO-ization hypothesis and urged scholars to study the effects of EU funding on NGOs (Roth 2007) and transnational mobilization (Paternotte 2013; Císar and Vráblíková 2010). All these accounts framed a hostile picture of activism in the region. More recent studies challenged the general understanding of the weakness and lack of capacity of movement actors to mobilize for policy change (Kriszan 2015) and emphasized a variety of mobilizations, groups and repertoires, depending on domestic political opportunities, available resources and collective identities (Jacobson and Saxonberg 2013).

This shift in tactical repertoires from contentious actions to lobbying and advocacy, occasioned by access to official politics, was associated with the institutionalization and professionalization of the feminist movement (Lang 1997; Alvarez 1999; Bernal 2000; Halley 2006). While some scholars insisted on the benefits of infusing feminist ideas and practices within the state (Banaszak 2010), others considered that institutionalization and professionalization made the feminist movement susceptible to co-optation, entailing demobilization and depoliticization.

However, charges of co-optation related to the movement's participation in policymaking were based on a romantic vision of an "autonomous" feminism outside the state. Critical accounts (Grewal in Roy 2017, 7; Roy 2015) reveal the normative formulations of such concepts, showing that they are an integral part of feminist politics today. Building on this perspective, the aim of this study is to explore how co-optation translates into the practice of doing politics by the feminist movement. In order to fill in the gaps in the co-optation literature, this analysis will explore the tensions and dilemmas faced by actors when engaging in cooperation with state institutions and undergoing a potential risk of co-optation, but also the strategies of negotiation and resistance.

Empirically, I draw on feminist epistemology, methodology and methods. Following a participatory approach to research, I combined feminist ethnography through participant observation, political activism and collaboration, with semi-structured interviews and document analysis. Participatory approaches to research were used both by social movement scholars (Melucci 1995) and feminist scientists on social movements (Taylor 1998; Taylor and Rupp 2005). I focus on the meso-level, specifically on the feminist movement community embodied in different locations, spaces and organizational structures. I loosely distinguish between street feminism (more informal groups and collectives), and NGOized feminism 
(more formal and institutionally tied), nevertheless understood as imbricated in a spatial and locative web.

To define the field boundaries in Romania, I combined a nominalist approach prior to starting the fieldwork, identifying feminist organizations and groups according to predefined criteria, with a realist approach relying on feminist activists' perceptions of who is part of the field. I aimed to bring together both formal organizations and informal collectives that inhabit the feminist movement community and intersect, through overlapping membership with other social movements such as the LGBTQIA+ movement, the right to housing movement or the anarchist movement. The research focuses on feminist organizations and groups that emerged after the 1990s. The interviews were guided by a loose grid of pre-identified themes and they lasted between 30 minutes and three hours, were tape recorded, transcribed, coded and analyzed using Nvivo software.

The article is organized as follows: the second section provides a brief overview of the feminist movement in post-socialist Romania with particular attention to institutionalization. The third section examines the scholarly contributions to co-optation, on which this analysis builds. The fourth section covers the empirical findings organized in various sub-sections analyzing co-optation in relation to state institutions or subsidizing bodies.

\section{NGO-ization \& feminist mobilizations in post-socialist Romania}

In Romania, during the first decade of post-socialism, when the anti-communist backlash was at its apogee, the feminist movement debuted in academia (Nimu 2015, 182), as an intellectualelitist endeavor within a mainstream liberal philosophy (Molocea 2015). Initially, there was no aperture for class, ethnic, and sexual diversity, and there was little capacity for mobilization (Molocea 2015). Nevertheless, Romani feminists organized since the 1990s, related to racist violence, hate speech and discrimination. Feminist activists organized both around formal NGOs and informal collectives within the cultural scene of the left, in an anti-authoritarian, anti-fascist, and anti-capitalist struggle.

At the end of the '90s, gender studies/feminist studies became institutionalized. The first program created, still in existence today, was an MA in gender studies at Scoala Nationala de Studii Politice si Administrative (SNSPA). Similar programs were subsequently created in Cluj and Timisoara (Borza, Grunberg and Vacarescu 2006, 37) but were rapidly dismantled (Vlad 2013, 35).

For post-socialist governments, gender equality was not a priority unless related to the EU accession (Massino and Popa 2015, 171), reflected in the adoption of legislation and public policies to comply with the acquis communautaire - a process labelled 'room service' feminism to emphasize the import character of policies and legislation (Miroiu 2004). Gender equality 
and non-discrimination bodies were created, such as Consiliul Național pentru Combaterea Discriminării (CNCD) or Agenția Naţională pentru Egalitatea de Şanse între Femei şi Bărbați (ANES) and Equal Opportunities Commissions in the Parliament.

On the mobilization side, the first feminist protest was organized in 2000 to end domestic violence, in response to an article published in Playboy Magazine entitled "How to beat your wife without leaving marks." In 2010, a protest against cuts to the childcare allowance was organized by mothers joined by feminist organizations and activists. In 2011, queer feminist collectives and feminist NGOs organized Slutwalk Bucharest, which strengthened cooperation and favored a transfer of confrontational tactics from informal groups towards formal organizations (Vlad 2015, 108-109). Since then, they have organized yearly protests and public actions for Women's International Day or the International Day for the Elimination of Violence against Women, participated in the 2012 anti-austerity mobilizations (Ana 2017), and the Rosia Montana protests in 2013 while some of them engaged in Anti-Eviction protests organized by the Common Front for the Right to Housing.

The availability of financial resources from international and European donors facilitated the expansion and development of these gender equality cells within the government, academia and civil society. Feminist NGOs started collaborating with the newly created agencies to advance the movement's goals and contribute to policy-making. They responded to a call for tenders from foreign donors to develop their organizational capacity, build networks and coalitions, train experts or create raising awareness campaigns. Nevertheless, cooperation with state institutions and the financial dependence on donors raised concerns about the risk of cooptation that would lead to goal displacement, appropriation of the movement's language and technique, channelling, pacification of critical issues or regulation of NGOs.

Yet, the feminist movement in Romania was never completely autonomous and unaffected by its collaboration with the hegemonic institutions that it tries to reform. Its growth is ingrained in coalitional politics that involve constant and dynamic negotiations between different actors - from feminist NGOs to self-managed informal collectives, gender equality bodies or other civil society allies. Viewing the feminist movement this way, co-optation is neither a choice nor an end in itself but an inherent aspect to the process of coalitional politics of the feminist movement.

\section{Co-optation}

The co-optation of social movements is thought to be a product of challengers' interaction with dominant institutions, state or vested interests, strongly encouraged by the process of NGO-ization. Co-optation has been addressed in the sociology of organizations and social movements literature, but also in feminist studies. 
In a study on the Tennessee Valley Authority (TVA), Selznic (1949, 13) defines cooptation as the process of absorbing new elements into the structure of a hegemonic organization, to avoid threats to its existence and stability. According to Gamson (1968), cooptation emerges when (1) moderate challengers gain access to the policy process without producing policy changes; (2) targets, antagonists, or sponsors appropriate and redefine the discourses of the challengers; (3) by financial donors who channel, transform and reorient the mandate of the social movement; and (4) through the adoption of empty-forms-withoutsubstance. Later, Gamson (2006) refers to co-optation as one possible outcome of social movements. The two clusters of the outcome measures are "acceptance" - concerned with the fate of a challenging group as an organization and, "new advantages" that refers to the distribution of new benefits to movement's beneficiaries (Gamson 2006, 113-114). Cooptation appears when there is an acceptance of the movement without new advantages.

Co-optation as a four-stage process was conceptualized by Coy and Hedeen (2005) based on the US community mediation movement and its co-optation by the state legal system. The first stage is inception, which captures a movement's formation, its demands for change, the potential establishment of alternative institutions and the perception for the need to reform by dominant institutions (Coy and Hedeen 2005, 410-412). The second stage is appropriation. Appropriation by language and technique includes the adoption of a movement's language and methods as well as its employment and redefinition against the initial purposes. Appropriation via inclusion and participation is realized: (1) through channelling, when hegemonic groups shift a movement's focus away from their substantive goals, towards moderate reforms; (2) through the inclusion of movement actors within governmental bodies with limited decisionmaking power; (3) through the pacification of movement concerns over critical issues under the impression that they are adequately managed and there is no need for pressure (Ibidem, 413-415).

The third stage of co-optation is assimilation of movement actors and goals through employment within dominant structures or state-certified training programs (Ibidem, 420424). The carrot-and-stick of funding pressures organizations to pursue specific goals. The last stage is regulation/response in which dominant institutions routinize and standardize practices, and regulate the qualifications of providers pressing for the professionalization of social services and endorsing dependence upon experts. Social movements might develop strategies to protect their alternative institutions, practices and cultures.

Feminist scholars have also contributed to debates on co-optation. Analyzing the US feminist movement, Ferree and Hess $(2000,141)$ found that the risk of co-optation appears when movement actors and leaders are absorbed within the hegemonic structures or when they are used to promote other goals than those of women. Analyzing EU gender policies, Stratigaki (2004) shows how co-optation unfolded in the case of reconciliation between work and family 
life, which shifted meaning from a feminist understanding that encouraged sharing family responsibilities, to a market-oriented understanding that encouraged flexible forms of employment. The original, feminist-inspired meaning of reconciliation between work and private life was altered, losing its potential for transforming gender relations (Ibidem, 32). In the co-optation process, a concept is not rejected but its meaning transformed and used for a different purpose in policy discourse (Ibidem, 36). Co-optation undermines gender equality by shifting meanings that deteriorate the policy impact and undermine mobilization around an issue of concern because it appears to be adequately handled by policy-makers (Ibidem, 36), which results in the pacification of concerns in Coy and Hedeen's (2005) model.

The neoliberal co-optation of feminism was addressed by Fraser (2013; Fraser and Honneth 2003) who argued that there was a shift from redistribution to recognition claims within the feminist movement that downplayed the critique of political economy at a moment when it was much needed - when neoliberal capitalism was on the rise. She argues that feminist critiques of economism, androcentrism, étatism and Westphalianism were re-signified in the context of rising neoliberalism with attacks from free-marketers of the welfare and developmental states. First, the shift from redistribution to recognition decoupled feminism from a critique of capitalism which it previously embraced. Second, feminist critique of androcentrism and the family wage was re-signified by neoliberalism serving today to intensify the valorization of waged labor by capitalism. Third, feminist critique of bureaucratic paternalism that originally aimed to transform state power into a social justice channel is now recuperated by neoliberalism and used to legitimate marketization and welfare-state retrenchment (Fraser 2013, 222). In postcolonies, the critique of state androcentrism favored a move towards NGOs to compensate for shrinking of the state, entailing grassroots' depoliticization and distortion of local groups' agenda in the direction of Western donors (Ibidem, 221). Lastly, feminist critique of Westphalianism proved ambivalent in the era of neoliberalism. What began as an attempt to build-up a transnational social justice movement through the organization of UN women conferences and engagement with European Union (EU) bodies, identifying local abuses and shaming states, transformed into a gap between professionals and grassroots through intensified "NGO-ification" (Ibidem, 223).

Angela McRobbie (2009) also argues that feminism has been instrumentalized. She shows how feminist elements such as "empowerment" and "choice" have been incorporated into political and institutional life and converted into a greatly individualistic discourse claimed by Western governments to define freedom for the rest of the world (McRobbie 2009, 1). The discourse on women's empowerment after the financial crisis marks the rise of a politicoeconomic project termed by Roberts (2015) as "transnational business feminism", referring to the joint efforts of liberal feminists together with states, funding institutions, NGOs and multinational corporations to construct women as brand-new resources capable of providing 
high returns in Western investment. This perspective resonates with Kantola and Squires' (2012) idea of today's shift from state feminism to market feminism.

Shifting the focus from how to avoid co-optation by hegemonic institutions to how to understand when engagement produces liberation, and when it fosters inequality and exploitation, Korteweg (2017) proposed a framework that distinguishes between the "who" and the "what" of co-optation, illustrated by the Sharia-based arbitration debate in Ontario. Co-optation, as a form of erasure, occurs as attempts to advance liberation instead further illiberal practices (Ibidem, 2). "Gender equality" becomes the "what" of co-optation, as a process that diminishes the liberatory potential ingrained in notions of freedom as practice while "immigrant women" are the "who" of co-optation, reflecting actors whose subjectivity becomes defined in ways that support illiberal ends (Ibidem, 3). In the "what" of co-optation, gender equality, originally understood as a liberal project, becomes a neoliberal one, which grants access to power and resources to certain categories. "Gender equality" functions as an empty signifier articulated in relation to liberal concepts such as progress and might not even be about gender, but a value of elites that helps preserve social hierarchies, including those related to post-colonial settler nation-states (Ibidem, 4). The "who" of co-optation starts with the radical idea that there is no a priori liberated subject and actors are embedded in social structures that contribute to the production of discourse and practice, where freedom as a practice makes some freer to act than others (Ibidem, 3). Co-optation results from power differentials between political actors, whose agency is embedded and shaped - though not determined - by structural contexts and conditions in which those less free to imagine or enact their liberation have their ideas and discursive practices mimicked by the powerful actors (Ibidem).

The solution to co-optation is not to stop political engagement, nor to see co-optation as the end of agency, but to critically examine the subjectivities produced through dynamic interaction that generated universalizing practices in the Sharia-based arbitration debate, with second wave feminist claims, contributing to the racialization of immigrant communities (Ibidem). The open question is whether co-optation represents the contemporary hegemonic mode of political engagement (Ibidem, 14).

Interviewed by Roy (2017) about co-optation and intersectionality, Grewal challenges the ideas of purity and autonomy of the feminist movement. Earlier, Grewal (2005) argued that if co-optation is a loss of feminism to other movements and institutions in terms of subject or strategies, we should acknowledge that feminism was never about gender alone as revealed by theories of post-colonialism and intersectionality, which showed how a gendered subject is coconstructed with other movements and institutions. The idea of an autonomous feminism is untenable because it suggests the need for a pure subject of feminism that dismisses other kinds 
of feminist activism and because there was no moment in which feminism was not attached to an institution - an empire, a state or a market (Roy 2017, 1).

Intersectionality offers the grounds to capture the complex history of the feminist movement and a solution to a narrative of co-optation that assumes a coherent, onedimensional movement, with a pure identity, produced via white privilege and imperial subject (Roy 2017, 6).

The normative formulations around co-optation and NGOs between neoliberal imperial evil and world saviors are based on this romantic vision of an "autonomous" feminism. NGOs, as part of feminist politics today, make women recognizable as specific categories of women, subsequently naturalized and universalized (Ibidem, 7). NGO women as a new professional class at the crossroads of class and globalization can reveal the kinds of subjects and feminisms that have been produced and the possibilities offered by NGOs for imperial and anti-imperial feminisms (Roy 2017, 7-8). Observations of how institutions, states, corporations, NGOs, the EU and communities embrace and use feminist ideas might help to address neoliberalism, beyond ideas of pure autonomous movement.

\section{Feminist co-optation and strategies of resistance}

The creation of gender-equality bodies opened a window of opportunity for the feminist movement in Romania, as these governmental bodies started to call for consultation or collaboration with feminist activists and NGOs. The debate on cooperation with state institutions and the risk of co-optation or remaining autonomous and advancing the movement's agenda with independent means sparked debates within the movement. Financial dependence, mostly on European and international donors also fosters exposure to co-optation and channelling. While these financial resources are vital for organizational survival and development, they do not encourage long-term strategies, being allotted for a short time span. This section will explore co-optation and resistance of NGO-ized feminism, in relation to state institutions and donors, through processes of institutionalization and professionalization together with financial dependence.

\section{IV.1. Risks of co-optation through institutionalization and professionalization}

As feminist NGOs were recognized as legitimate partners of the state, especially by gender equality and non-discrimination bodies, they were sometimes invited to collaborate. Nevertheless, frequent political changes prevented continuity in the relationship. Regarding state institutions, the risk of co-optation appears in relation to the process of inclusion and participation that involves contractual relationships and regulation. 
Becoming a legitimate partner and participating in the decision-making process, through official channels, comes in tandem with a pressure towards formalization and professionalization. The state allocates the space within the framework of civil society where these organizations can exist and participate; it gives them financial incentives, but also legitimacy to formalize. The ongoing negotiations take place in relation to issues of content legislation, public policy, or framing of some issues.

\section{IV.1.1. Professionalization, expertise and legitimacy}

It is not only the form that counts - the NGO form that is constraining regarding procedures and manner of operation - but also the enclosure of expertise within a certain institutional framework, which brings official recognition and confers the legitimacy given by a profession, being an incentive for professionalization.

In Romania, the professions of expert and technician in equal opportunities were introduced in the register of occupational classifications in Romania - COR (Classificarea Ocupatiilor in Romania) - due to the long-term advocacy carried out by some feminist organizations, especially by Centrul Parteneriat pentru Egalitate (CPE). One of the CPE employees, who previously worked at ANES (the National Agency for Equal Opportunities between women and men) recalls the process of introducing these two professions into the corpus of occupations in Romania:

I worked at ANES initially, and ANES was very interested in CPE's work, especially when, in 2006, CPE introduced a request to include the profession of gender expert in the COR. But this request was met with several refusals by the Ministry of Labor. ANES always expressed support for this request and, in 2014, there were no more obstacles. Obviously, the proposal was subject to some modifications because you cannot expect the proposal to appear exactly as you submitted it, but it was introduced. And this is a very good result of CPE's advocacy policy extended over a long period of time - nine years of advocacy on a theme (she laughs) - but it is a result that would not have been achieved if the CPE would not have insisted. (M.T. - CPE)

While it was a long-term and successful process of advocacy, the limits of its success were set by the terms of negotiation regarding the framework in which the professions of equality of chances expert and technician were enclosed. It concerned the regulation of the educational and professional training, competencies or the conditions of access to the program in relation to the level of study or other special requirements. This case exposes the potential risk of cooptation, as power imbalances between the state and the feminist movement organizations could have weighted heavily against the latter. But not every case of collaboration with the state 
should be seen as co-optation, rather a movement's collaboration with official institutions should be understood as containing in itself the potential risk of co-optation, due to power asymmetry, external events and new elements into volatile opportunity structure dimensions, such as the configuration of power on the left that can occasion shifts in negotiation. The case is more representative of a channelling process in which governmental actors tried to dissuade CPE's lobbying attempts to gain recognition for their professional expertise and their proposal was subject to long negotiations and multiple modifications. Beyond the idea of purity and the autonomy of the movement, deciding to collaborate with the state allowed feminist NGOs to professionalize their activity and experts to gain formal recognition, a goal that they could not achieve on their own.

\section{IV.1.2. Inclusion or marginalization: autonomy versus dependence}

Debates around autonomy versus dependence that would entail a risk of co-optation appeared in relation to state institutions and funding bodies - public or private. Recognized as legitimate actors and participating in decision-making, NGOs' unbalanced power dynamics with official institutions, especially when playing in the official arena, contributes to altering a movement's claims in favor of the state (C.P. Front). To compensate for power asymmetry, or failure of negotiations on the official terrain, feminist organizations step out of the conventional political channels and resort to contentious actions. The choice among confrontational and/or cooperative tactics is the trump card of the movement that helps answer the risk of co-optation, not by avoiding political engagement with state institutions - a process inherent to the institutionalization of feminism - but to critically engage with the political arena, choosing the appropriate tactics, on different fronts, in the service of the situation.

The false debate around the idea of pure autonomy is also illustrated by the relationship between feminist NGOs and informal collectives that consider it necessary to engage both in collaboration in official politics - through lobbying and advocacy - to improve laws and policies, but also in contentious actions and self-managed organizing for consciousness-raising, self-help, or political resistance. Activists in self-managed collectives do not discard the work of feminist NGOs as being merely reformist and acknowledge that some activists working in professionalized organizations have radical and critical positions towards NGOs activities.

One activist from the Dysnomia collective mentions that feminist NGOs:

Omit a lot of marginal identities, omit what intersectional feminism does in the feminist struggle, omit the intersection of class, race, gender identity, sexual identity, their positions being rather liberal. But at the same time I think the work they do it's important. It seems to me that we should appreciate their work and I will not reject it; I will not suppress the work they do. There are women we know, with whom we have 
discussions, who have good political positions but who are part of this structure that works like that, it's the European project that works like that, that's why that money has been allocated. (R. - Dysnomia)

Regarding contractual relationships, interviewees mention that the situations in which NGOs make alliances with "the enemy", i.e. the state most often, the risk of co-optation becomes difficult to counter when power dynamics are unbalanced (C.P. - Front, C.T. - Filia). This was the case with the START project, carried out by the Department of Equal Opportunities between Women and Men together with the National Academy of Intelligence and funded by the European Social Fund (ESF) - a 38-million-euro project. The project aimed to contribute to the prevention and fight against domestic violence by creating an infrastructure dedicated to these objectives. However, the project was revealed to be a national fraud and a money laundering investigation took place. The project manager was a former employee of the Interior Ministry. Although the project was highly controversial with regard to transparency and the use of funds, some feminists, NGO members (from Filia Centre) or providers of services for victims of domestic violence (from Transcena Association, Sensiblu Foundation or Anais Association) worked as gender experts on the project. Activists fighting to end violence against women had high expectations from the START project since it was the first time that such significant resources were allotted to develop an infrastructure to address this phenomenon. But for service providers who constantly struggle to maintain their activities in precarious financial conditions, the way the project money was used was considered a waste. However, they were not comfortable criticizing the project, as they depended on the National Agency for Equal Opportunities between Women and Men (ANES), which has responsibilities related to minimum quality standards for social service providers. When some activists denounced START, the experts hired for the project tried to prevent criticism from the feminist comrades and were not comfortable themselves criticizing the project because they collaborated with state institutions and were bound through inflexible employment contracts and very rigid confidentiality clauses that prevented them from talking about it (C.T. - Filia; C.P. Front).

A former member of a feminist NGO, who worked at the time at the Department for Equal Opportunities and also in the START project, mentions on her Facebook page, sharing a newspaper article with the title "Fraud of 170 million euros for a quality life...":

I am sorry to have worked on this project and I am happy to have left the project and the country in time. With this European project and my work in the Department for Equal Opportunities, my last hopes for a change for the better have died. I hope that the feminists and activists who remained there are more cautious and less naive. (C.T. Filia ) 
Another activist insists that co-optation takes effect when NGOs ally with the state like in the START project: "it kills some of your independence and activism and your capacity to criticize and to critically engage with a state institution" (C.P. Front).

A contractual relationship interrelated with financial dependence might occasion an exclusion from the decision-making process. Professional activists are contracted to provide expertise within precise confines, established a priori. They are not involved in the build-up process of the project, being unable to denounce the way a project is ran and unfolds. One project, financed through SOP HRD and initiated by the Order of Nurses and Midwives in Romania, aimed to provide training for women employees in the health care system. Feminist and gender equality professionals were contracted as experts for trainings and workshops and, in accordance with the EU's transversal principle of gender equality, applied through gender mainstreaming. Feminists hired in the project were very critical towards it, considering that it had a negative impact on the system. They argued that apart from "training cheap labor for abroad", those women who were trained did not have decisional power within the medical institutions they were part of and could not make changes regarding workplace sexual violence or the implementation of protocols that would give women the possibility to file complaints in total safety (V.A. - Front, Filia, O.C. - Front). One of the experts adds that without decisional power and "since their bosses remain uninformed, nothing will change and it is because of this that the impact seems reduced to me" (O.C. - Front).

What does this mean for a movement that wants to be subversive? Within the movement, discussions and reflections regarding the symbolic value and meaning of the terms of collaboration with different actors - public or private - are ongoing. Offering consultancy is the same as selling any other service? (M.R., Front)

\section{IV.1.3. Instrumentalization versus institutional discursive socialization}

Collaboration between state institutions, especially ANES, and feminist organizations is considered mostly mercantile, meaning ticking a collaboration or consultation with NGOs because of an EU recommendation or an obligation from international bodies with whom the country is bound legally through conventions. Openness to collaboration depends on the government in power and varies from institution to institution. Within the process of inclusion and participation, some feminist activists and professionals were hired within these genderequality bodies and contributed to the institutional discursive socialization of some state employees. One of the oldest employees and former secretary of state of ANES recalls the exchange of knowledge: 


\begin{abstract}
"We were a very young team then, all university graduates. The youngest of us, X, had gender expertise because he had completed the gender studies Master's, or was in the last year. We debated many issues... I was coming to work at 7.30 in the morning and staying until the evening to debate various issues. The first time, he gave me Drumul catre autonomie ("The Road to Autonomy") by Mihaela Miroiu and told me "Read it. After you read it, we talk". And then my world broke completely. That was it. Since then, I started a Master's, but I did not finish it; I gave birth to my daughter, but I read a lot of literature, because he gave me, he was my supplier, my feminist literature dealer. And we slowly started to function as an institution as well - we also had a headquarters, we also had the necessary facilities..." (M.C., ANES)
\end{abstract}

This situation is reflective of the scholarly debates around the possible benefits of infusing feminist ideas within the state and function as a contamination process.

\title{
IV.1.4. Occupy the space: resistance to the current hegemonic order
}

Rather than just risking blunt co-optation, feminist NGOs, who engage in formal politics, occupy a space in the official political arena and secure opposition: first. to the present hegemonic order, including the state - an order that tends towards a normalization of the neoliberal consensus (Mouffe 2000); and second, in relation to counter-movements and other antagonists, providing an alternative to the right-wing and radical right discourses that are gaining momentum in recent years.

Critics of NGO-ization argued that NGOs address issues only in a politically acceptable manner (Alvarez 1998, 306) and target a mere reform of the state that might create new dependencies and regulations for women (Lang 1997, 112) or as agents of imposed neoliberal reforms by Western states (Jad 2007). Without denying such critical stances as they are grounded in instances of instrumentalization and mercantile cooperation, as previously shown, I suggest that through participation in institutional politics, feminist NGOs and activists occupy a space that otherwise would have been unoccupied, free and open to use by conservative groups or counter-movements, which often supported legislation and policies aiming to restrain various rights such as the right to abortion (A.F.1, Filia; A.T. - Filia; M.R. 1 - Front).

One of the strikes of the pro-life movement strongly supported by the Orthodox Church within their long-term anti-abortion campaigns was the legislative initiative by MPs Marius Dugulescu and Sulfina Barbu from PDL (Democratic Liberal Party) to establish counseling cabinets for the pregnancy crisis (my emphasis) and introduce compulsory counseling for women who want to have an abortion, including showing audio-video materials regarding abortion procedures and information regarding the fact that "from the moment of conception, the embryo is a human being in the full sense of the word, whose life will cease following the 
medical procedure". In the explanatory memorandum of the law, the deputies unilaterally promoted and supported the activity of pro-life movement organizations or religious organizations.

During the conference organized to present the legislative proposal, hosted by the Parliament, in March 2012, the room was physically divided: on the right side, sat pro-life organizations such as Pro-Vita, the Families Coalition and allies such as religious organizations; and on the left side, sat feminist organizations, representatives of the Antidiscrimination Coalition, LGBTQIA+, Romani and human rights organizations. The latter organizations coalesced to oppose to the legislative proposal and organized a rigorous campaign with both domestic and international support, until September 2012 when the proposal was rejected in the Parliament.

One feminist, who participated throughout the process recalls:

\begin{abstract}
"It is against this stuff today that it is very hard to fight, very very hard, because what can you do? Here I am with you, with X and Y creating NGOs, protesting and screaming like three wimpy cats in the rain, in the public market, and these people have some millions of dollars. You, who are you? Who are you to buy TV broadcasting space, what? There is such an explicit, absolute power imbalance." (M.R. 1 - Front)
\end{abstract}

Apart from solid infrastructure - organizational and financial - with enormous support from the Romanian Orthodox Church, the pro-life movement and the Families Alliance have an effective communication strategy: formally detaching themselves from extreme-right organizations, bringing women to the forefront with rainbows on their websites, using both frontal and subtle tactics, such as trying to obtain the recognition of the fetus as a human being in order to avoid other parliamentary procedures in their way towards banning abortion. (A.T. - Filia)

Beyond risking co-optation, engaging with the state allows feminists to occupy a space in the official politics, to position themselves as pawns on a chessboard in relation to governmental agencies and state institutions as hegemonic institutions, but also in relation to counter-movements such as pro-life movements and the extreme-right.

The argument for the necessity to constitute an opposition to pro-life movements, extreme-right movements, theorized under the general umbrella of anti-gender mobilizations (Kuhar and Paternotte 2017) is similar to feminists' urging about the dangers of giving up opposition while taking for granted the gained rights. This shows the need to act both in the official political arena and in contentious street politics to construct and maintain alternatives to the existing hegemonic order and to counter-movements. It resonates with Hodzic's research where she finds that Ghanian feminists see no value in opposing the state "for the sake of taking a pure stance" but they try to re-gender state institutions, establishing 
collaborations with public institutions but at the same time being critical about them, considering them both "dangerous and generative" (Hodzic 2014, 233-234).

\section{IV.2. Co-optation through financial dependence}

Financial dependence, amplified by the lack of alternative independent resources that could assure an NGOs' survival, increases the risk of co-optation, which in this case is related to the multiplicity of funding sources. Co-optation through financial dependence involves four dimensions: channelling through increased bureaucratization and project-based work; donors' agenda and priorities; constant evidence of the social needs to donors that favor mostly a oneshot approach; the risk of restrictions and censorship.

Feminist organizations distinguish among two periods after the fall of the state-socialist regime regarding donors' practices. Before entering the EU, sponsors were more flexible, there was less bureaucratization and "a less expert attitude" (C.B. - Filia). This allowed feminist professionals in NGOs to negotiate with donors, the terms of project implementation or to explain when some aspects did not go as planned in the initial funding application. This initial flexibility of donors allowed for bring local issues and knowledge to the forefront, but also to gain expertise and competencies, learning about project management. After EU accession, NGOs were awarded according to their organizational capacity. The more grassroots feminist organizations did not conform to the European donors' requests and, to survive, entered into partnerships with bigger organizations or state institutions who had the organizational capacity and resources to apply for European funds, such as universities, ministries and hospitals (C.B. - Filia). The second wave of funding brought increased bureaucratization, which diverted time. Feminists in NGOs confess that they spend around half of the time devoted to a project to bureaucratic activities connected to donors, instead of working for and with beneficiaries. This also lowers their reactive capacity for mobilization and the degree of politicization of certain issues.

\section{IV.2.1. Channelling through bureaucratization and project-based work}

Channelling through increased bureaucratization and project-based work implies that considerable resources of time and personnel are channelled towards administrative and bureaucratic activities: fundraising, evaluation and justification for subsidizing bodies, writing reports and compiling supporting documents. Project-based work is a logic of action endorsed by donors by offering thematic short and medium-term funding for projects. Organizations do not have access to structural funding that can ensure organizational continuity and long-term strategies; their survival depends on the projects they have. Hence, feminist NGOs' financial 
resources are composed of a mosaic of project funds from multiple donors. They spend substantial time searching for grants and writing applications and, if they get the grant, on writing reports and evaluations. This happens in the detriment of reactive, contentious actions, supporting a certain degree of demobilization.

Concerning organizational survival by engaging in projects overloaded with bureaucracy, one interviewee from Filia Center recalls that apart from the positive things that Filia does, all of them are built on constant negotiations and tensions regarding balance sheets, audit, payments, budgets, problems with reports - all these representing the work behind the scene that is mostly unseen (A.T. - Filia). Bureaucratic activities, many times overlooked, should have a place in this narrative because they constrain, in the sense that "you need to make some compromises on taking projects because otherwise the organization cannot survive", in the most basic way with office rent and bills (A.T. - Filia). Related to compromises such as taking projects overloaded with bureaucracy, the president of the same association recalls:

\footnotetext{
"We participated in this project on equal chances for active women that aims to support women to become competitive on the labor market. This project is a SOP HRD and it offers a bigger salary, but is loading us with bureaucracy. Nevertheless, if we have a bigger salary, we can bring more money for the organization and these are some informal policies at the level of organization, which do not represent a sustainable method of survival. Another colleague and I are constantly donating money. I apply for different funds, but if we do not win the grants, all our labor contracts end here." (A.F.2. - Filia)
}

The ALEG Association recalls that their first funds, before entering the EU, were awarded from sponsors considered more flexible, such as the Global Fund for Women or Global Fund for Children. After EU accession, ALEG members had to deal with the bureaucracy of European and Romanian funds, but they were already used to it, more mature as an organization and able to manage the heavy bureaucracy without giving up (P.P. - ALEG). One member recalls one of the biggest projects they implemented which was the build-up of a crisis centre, a pilot centre for counseling in cases of sexual violence. She explains that half of her time as project manager was used to do bureaucratic work. She considers this excessive because it takes from the time that should be allotted to those for whom the service is created, for the coordination of the service, for adjusting the procedures (A.V. 1 - ALEG). Though much of the bureaucracy is meaningless, she is aware that some bureaucratic work is useful for establishing evaluation procedures and measuring the impact of the service created:

\footnotetext{
"This is the bureaucratic part of the service that would make sense and would be worth investing time in, but instead we lost a lot of time with the bureaucracy demanded by the donor where there are a lot of requirements with notifications every time you do
} 
not fall into a budget line; and all these notifications had many attachments and explanations and very exhaustive period reports.” (A.V. 1 - ALEG)

Similarly, members of the Front Association tried to avoid the Sectoral Operational Program Human Resources Development (SOP HRD) financed through the ESF because it set some obstacles beforehand, as there is a cash-flow requirement to be able to advance money and start the project and because it is loaded with bureaucracy. They preferred to apply to Fondul ONG, which gives less money, but has more flexible conditions (C.P. - Front; O.C. - Front).

Feminist activists have to consider that using organization's resources for predictable, well-planned actions and for bureaucratic activities related to donors' accountability leaves fewer resources available for non-predictable and reactive actions. The consequence of financial dependence and the precarity of project-based work loosens NGOs' reactive capacity regarding urgent, imperative concerns and decreases involvement in grassroots activism and contentious actions (C.B. - Filia, C.P. - Front, M.M.1 - CPE).

The case of a gang rape that involved seven young men from the Moldova region who were tried in freedom was emphasized during interviews as an important case with low mobilization for reaction. One feminist recalled that NGOs and the larger feminist community did not organize any public action of protest because "as simple as that, they did not have time or they had other priorities. Other priorities like projects, you know?!” (C.P. - Front). She continued: "And it seems to me that this activism where you do not react although it is a very important and serious matter - because you realize that sexual violence, at least in Romania, is a critical and serious issue and it would be a huge priority but you lose yourself with other things like projects" (C.P. - Front).

The potential trigger of a gang-rape case was not sufficiently handled - interviewees emphasize (M.M.1 - CPE, C.P. - Front, V.A. - Front, Filia, A.V. 1 - ALEG) - as to mobilize the public in a wider movement against sexual violence. However, the Network Break the Silence against Sexual Violence, which gathers NGOs involved in preventing and combating sexual violence, wrote an open letter to the Romanian President Klaus Iohannis, questioning the trial in freedom of the offenders. The Network asked the Ministry of Justice to make public the means by which it was decided to order the transposal of the Directive 2012/29 / EU establishing minimum standards on the rights, support and protection of victims of crime in the national law and the way they will implement them. The Network also asked for public consultations with representatives of expert organizations and to correctly transpose and implement the directive. Finally, they sent a message of solidarity with the abused girls and women and their families .

The lack of (independent) resources or their scarcity intensifies the tension between engaging in contentious, disruptive actions close to the SM type or in policy change actions and collaboration with state institutions. One activist, a former volunteer at Filia, recalls that 
one of the last actions they organized before she left the organization was Slutwalk Bucharest. The president of the organization back-then opposed Filia's institutional participation or its name associated with the protest, arguing that "it looks bad on Filia's CV" and it might preclude possible funds from the Soros Foundation or embassies since it would appear as too radical and an anti-system organization (V.A. - Front, Filia). However, a few Filia members contributed to the organization of Slutwalk and participated in the march. A few years later, another feminist organization was inquired by donors following a grant application in relation to the organization of Slutwalk (I.T. - Front).

\section{IV.2.2. Social needs and donor's one-shot approach}

With the new wave of funding, proving to European sponsors the special needs within local communities became more difficult. There is a gap between donors' perceptions about the imperative needs and problems of groups and communities - and NGOs understanding of those issues. Donors maintain control over resources and their distribution, having the power to decide to whom, how and for what purposes resources will be allotted. This asymmetrical relationship between donors and NGOs reveals the disconnection between acceptance of progressive postulates and dismissal of advantages, such as the refusal of institutional support in the following cases. One employee of an LGBTQIA+ organization in Bucharest mentions that HIV prevention is still needed but "this is the perversity: that you still need this but you have to prove to sponsors that it is sustainable and donors, unfortunately, are dictating the social movement up to a point, even if not completely." (S.P. - ACCEPT, Biblioteca Alternativa).

Similarly, the ALEG Association created specialized service for victims of sexual violence, working from a feminist perspective, a unique service in Romania, implemented with resources from NGO Fund. ALEG wanted to continue offering the service as there was a proven necessity in their view, based on the experience of the pilot project. However, they did not manage to win funds, as donors rejected their application, considering that ALEG did not prove the special need for the service. For ALEG it was difficult to see the subject of sexual violence rejected, knowing from the ground the great need for specialized services (P.P. ALEG).

While for domestic violence, some infrastructure of services was developed, for sexual violence it is still deficient. Sexual violence can be both with a partner and included in domestic violence, but also with a non-partner, outside the family environment and no rape crisis services are provided. Romanian legislation concentrates on violence within the family. Victims of sexual violence outside the family are protected by the penal code, but there are no specialized services for them. An activist explains: 


\begin{abstract}
"We think it is very important to work from a gender perspective, from a feminist perspective in the area of sexual violence because it is very easy to re-traumatize if you don't help the victim understand that the causes of the violence she suffered do not depend on her, that she did not do something wrong. This approach is lacking within state institutions' intervention and this is why what we bring has an added value, but unfortunately it is not sufficiently important for some donors." (A.V. 1 - ALEG)
\end{abstract}

ALEG decided to maintain the specialized service for sexual violence, but since financing is lacking, they have had to work as volunteers providing counseling, sharing information, working with lawyers who offer pro bono support, but it is not able anymore to reimburse medical-certificates or to support victims to the same extent (A.V. 1 - ALEG, P.P. - ALEG).

\title{
IV.2.3. Adjustment to donors' agenda and priorities
}

In the context of NGOs' financial scarcity, co-optation through financial dependence concerns the contingent pressure from a donor's agenda. NGOs indicated the limiting character of the donor's agenda and priorities that dictate the projects to be funded and the issues addressed, sometimes to the detriment of local needs when they do not correspond to the agenda.

The new wave of EU financing, the largest donor in Europe, came with the top priority of integration of vulnerable groups in the labor market. Consequently, many NGOs implement projects that aim to integrate vulnerable women on the labor market. The Centre Partnership for Equality in Bucharest (CPE) implemented two SOP HRD projects: one on innovation and promotion of women in the labor market; and the other on the integration and promotion of women in the labor market, both targeting unemployed women between 16-35 years old. To achieve this goal, CPE organized different activities: focus groups with unemployed women, to elaborate a needs analysis to further build-up a course on social and civic competencies; ten campaigns to raise awareness; five courses on social and civic competencies at the end of which participants would receive a diploma and 250 RON (around 50 euros); seminars for public authorities, NGOs and vulnerable women in the labor market; a study visit in Milan for public authorities to exchange good practices on gender equality (M.M.1 - CPE).

Feminist NGOs question themselves about the potential contributions from these kind of projects in accomplishing the movement's goals. One activist mentions that these projects aiming to integrate vulnerable women in the labor market are not sustainable and amplify and maintain class divisions between women, with some women being empowered on the back of other women (C.B. - Filia). She further explains:

"I think a lot changed with the new wave of financing from the EU. This means that when you train 500 women to become baby-sitters, you think that you helped them. 
And the problem is that this is an absolute systemic phenomenon. All these projects that follow an issue theoretically exasperate me - like you teach another hundred women to better write their CV and to participate in job interviews. For me this is an illusion to believe that we can do this for all women, like the labor market would be an endless supply of decent jobs. And I think we need an intersectional feminist critique of capitalism because many women are emancipated at the expense of other women." (C.B. - Filia)

Feminist NGOs criticize the European-funded projects that aim to contribute to the integration of vulnerable groups of women in the labor market, considering that they address neither the local issues of women nor the root causes of their oppression and vulnerability. Being poor, some women from the target group are incentivized to participate in the seminars organized through these projects to get the meagre sum of money that they receive at the end (M.M.1 - CPE, A.S. - CPE). Likewise, representatives from state institutions such as school inspectorates, institutions for retirement, and employment agencies were incentivized to participate in trainings with the possibility to apply for a study visit abroad or other benefits.

Channelling, through financial dependence, donors' agendas and priorities, also means alienation and self-alienation from the grass-root movements, including from the working class people, by being exposed to the mirage of inclusion to the elite or at least an upgrade to the new middle-class. The perversity of this phenomenon is to be understood in the context of the precarious working conditions of many feminist NGOs' employees and activists. There is a gap between NGO experts with high salaries and other feminist employees who perform a great deal of voluntary work in addition to their NGO contract. One former Filia member who later joined an informal queer feminist group explains that "for civil society, anti-capitalism is against its interests" and everything that means civil society fits the neoliberal model very well (C.B., Filia). She argues that the professionalization of feminism in Romania during the last twenty five years was profitable for some people:

\footnotetext{
"A moment of awakening was when I realized that people really think about this as a job and they take money. It seemed to me they take a lot of money, especially after the SOP HRD projects appeared [...] And I work all day with poverty rates and threshold -100 euros - and then I see a salary like this...it gives me a headache. For many people, it is profitable to do this [...] And when it's not about money, it's about the CV - you're building your resume. You get a better job. When you enter the mainstream civil society, it helps you in this neoliberal system. For me, the first alarm sign was that if we would really be anti-system activists, fighting systemic injustice, it should be harder. I mean, you should not feel like you can actually go on.” (C.B., Filia)
} 


\section{IV.2.4. Risk of restrictions and censorship}

The last aspect of co-optation through financial dependence concerns the risk of restrictions and censorship by donors. Constraints in terms of actions, discourse and language shape the activities and framing of feminist NGOs and they appear both indirectly, through regulations provided through donors' guidelines for applications and call for tenders, and directly, through rejecting reports and other written, audio or video materials submitted to donors for evaluation until they fit the sponsor's frame or agenda.

One Filia member explained that when doing research about the impact of the economic crisis on women financed by the United Nations Development Programme (UNDP), when they sent the final book version which resulted from the research, the sponsors rejected it initially saying that they would not publish the report until it was re-written. They were disturbed by the fact that the authors criticized the austerity measures implemented by the government and they argued that the project was supposed to be about the impact of the economic crisis and not about the austerity measures. Those involved in the research replied that they cannot separate the two of them. A Filia member recalls: "we tried to resist it as it seemed to be overt censorship and then they said we should at least rephrase some things as there is too much essay and they want bullets. Anyhow, I understood that they had many interactions at the time with the governing party and that's why they asked for a re-write." (C.B. - Filia). Similar situations were not uncommon. In another case, donors conditioned funding on changing the title of a project from what activists called "misogynistic advertising" to "disrespectful advertising", erasing the element of gender - the objectification of women by the mass media and the promotion of gender roles rooted in structural inequalities - revealing the subtle coercion with depoliticizing effects (A.T. - Filia, C.B. - Filia).

Feminist NGOs stressed the need for independent funds, such as the Frida Fund, that target feminists' work to tackle different issues and is intended for formal and informal organizations. Having to compete for funds with all the social causes raises problems for feminist organizations (A.V. 1 - ALEG; P.P. - ALEG).

\section{Conclusions}

Risks of co-optation of the feminist movement appear when entering into a collaborative relationship characterized by a substantial power asymmetry, such as those with state institutions or donors.

Collaboration with state institutions and gender-equality bodies opened a window of opportunity for the feminist movement to contribute and influence policy-making in crucial areas, such as gender equality laws and policies, non-discrimination and violence against women. The formal recognition of the experience and knowledge of the feminist activists and 
later professionals was translated into the institutionalization of their expertise. However, feminist NGOs view alliances with the state as both dangerous and constructive, considering that mobilization alone does not suffice and other strategies that do not just target but also involve state actors are necessary.

Cooperating with state institutions does not automatically entail co-optation, nor does it involve stopping being critical towards the government or stopping engaging in contentious strategies. When institutionalized tactics such as lobbying or advocacy failed, organizations adopted more disruptive repertoires.

The risk of co-optation appears also when feminist NGOs enter collaborative contractual relationships with rigid clauses and limited decision-making power. Beyond the false idea of pure autonomy, the necessity to act on urgent social issues by improving legislation and policies offers limited choices to feminist NGOs but to participate in the official political arena. The scarce independent financial resources pressured NGOs to search for funds from public or private donors. However, the power asymmetry between NGOs and donors and the financial dependence sometimes weigh against the movement. The rare, limited state funds pushed feminist NGOs to collaborate with European and international donors. European funds channelled NGOs work by overburdening them with bureaucracy and through project-based work that endorse a one-shot approach. Proving the urgency of the social needs that they want to address sometimes clashes with donors' agendas and priorities. Risks of restriction and censorship appear when NGOs' perspectives collide with those of donors.

However, the answer to the risk of co-optation was not to stop engaging politically with state institutions, thought unaffordable by many activists, but to critically engage with the political arena by occupying a space in the formal official politics to foster norm diffusion or institutional discursive socialization, to secure opposition to the current hegemonic order that normalizes neoliberalism and to provide an alternative to the right wing and radical-right movement and discourses that are gaining momentum during recent years. 
SP Accept, Biblioteca Alternativa Bucharest

MM1 CPE, Bucharest

CB Filia, Centrul Feminist Sofia Nadejde, Bucharest

AS CPE, Bucharest

BM Filia, Bucharest

A.M. A-Casa, Cluj

B.T. Biblioteca Alternativa

T.D. Biblioteca Alternativa

I.C. Filia

C.S.1 Front

M.R.1 Front

C.L.1 Dynsomia, Claca, Biblioteca Alternativa

R.C. A-Casa

O. Dysnomia

c.c. $\mathrm{CPE}$
June 2015

June 2015

June 2015

February 2016

January 2016

July 2016

June 2015

June 2015

June 2015

June 2015

June 2015

June 2015

July 2016

July 2016

June 2016 


\section{References}

Ana, Alexandra. 2017. "The Role of the Feminist Movement Participation during the Winter 2012 Mobilisations in Romania.” Europe-Asia Studies vol. 69, no. 9: 1473-1498.

Borza, Ioana, Laura Grünberg, and Theodora-Eliza Vacarescu. 2006. Cartea neagra a egalitatii de sanse între femei si barbati în România. Bucuresti: AnA.

Cirstocea, Ioana. 2010. "Du genre critique au genre neutre: effets de circulation." In Au-delà et en deçà de l'état: Le genre entre dynamiques transnationales et multi-niveaux. Louvain-La-Neuve: Academia Bruylant: 183-196.

Císař, Ondřej, and Kateřina Vráblíková. 2010. “The Europeanization of Social Movements in the Czech Republic: The EU and Local Women's Groups.” Communist and PostCommunist Studies vol. 43, no. 2: 209-219.

Coy, Patrick G., and Timothy Hedeen. 2005. "A Stage Model of Social Movement CoOptation: Community Mediation in the United States." The Sociological Quarterly vol. 46, no. 3: 405-435. https://doi.org/10.1111/j.1533-8525.2005.00020.x

Ferree, Myra Marx, and Beth Hess. 2000. Controversy and Coalition: The New Feminist Movement Across Four Decades of Change. New York-London: Routledge.

Fraser, Nancy, and Axel Honneth. 2003. Redistribution or Recognition?: a Political-Philosophical Exchange. London-New York: Verso.

Fraser, Nancy. 2013. “How Feminism Became Capitalism's Handmaiden - And How to Reclaim It." The Guardian October 14. Retrieved from: https://www.theguardian.com/commentisfree/2013/oct/14/feminism-capitalisthandmaiden-neoliberal (accessed 20.04.2019).

Fraser, Nancy. 2013. Fortunes of Feminism: From State-Managed Capitalism to Neoliberal Crisis. London-New York: Verso Books.

Gal, Susan, Kligman, Gail, and Delia Răzdolescu. 2003. Politicile de gen în perioada postsocialistă: un eseu istoric comparativ. Iasi: Polirom.

Gamson, William A. 1968. Power and Discontent. Homewood, IL: Dorsey Press.

Gamson, William. 2006. "Movement Impact on Cultural Change." In Culture, Power and History: Studies in Critical Sociology. Eds. Stephen Pfohl, Aimee Van Wagenen, Patricia Arend, Abigail Brooks, and Denise Leckenby. Leiden: Brill.

Grewal, Inderpal. 2005. Transnational America: Feminisms, Diasporas, Neoliberalisms. DurhamLondon: Duke University Press.

Grunberg, Laura. 2014. "Lived Feminism(s) in Postcommunist Romania." In Theorizing NGOs. States, Feminisms and Neoliberalism. Eds. Inderpal Grewal, and Victoria Bernal. Durham: Duke University Press.

Jacobson, Kerstin, and Steven Saxonberg (eds.). 2013. Beyond NGO-ization. The Development of Social Movements in Central and Eastern Europe. Farnham: Ashgate.

Kantola, Johanna, and Judith Squires. 2012. "From State Feminism to Market Feminism?" International Political Science Review vol. 33, no. 4: 382-400. https://doi.org/10.1177/0192512111432513

Korteweg, Anna C. 2017. "The »What« and »Who« of Co-Optation: Gendered Racialized Migrations, Settler Nation-States and Postcolonial Difference." International Feminist Journal of Politics vol. 19, no. 2: 216-230.

https://doi.org/10.1080/14616742.2016.1191286 
Krizsan, Andrea (ed.). 2015. Mobilizing for Policy Change: Women's Movements in Central and Eastern European Domestic Violence Policy Struggles. Budapest: Central European University.

Massino, Jill, and Raluca Maria Popa. 2015. "The Good, the Bad, and the Ambiguous:

Women and the Transition from Communism to Pluralism in Romania." In Gender (In) Equality and Gender Politics in Southeastern Europe. Eds. Christine Hassenstab, and Sabrina Ramet. London: Palgrave Macmillan.

McRobbie, Angela. 2009. The Aftermath of Feminism: Gender, Culture and Social Change. Los Angeles: Sage.

Miroiu, Mihaela. 2010. "A Mind of Our Own. Gender Studies in Romania.” Aspasia. The International Yearbook of Central, Eastern and South East European Women's and Gender History vol. 4: 167-176.

Molocea, Andreea. 2015. "Re-construcția feminismului românesc în cadrul mișcării de femei (1990-2000).” In Mișcări feministe și ecologiste în România (1990-2014). Ed. Mihaela Miroiu. Iasi: Polirom.

Nimu, Andrada. 2015. "A Theoretical Approach To The Effects of External Funding on Women and Gender Based NGOs in Romania and Poland." Europolity vol. 9, no. 1: 161-188.

Paternotte, David. 2013. “Transnationalisation/Mobilisations Transnationales”. In Dictionnaire genre et science politique : concepts, objets, problems. Eds. Catherine Achin, Laure Bereni. Paris: Presses de Science Po: 503-514

Petrova, Tsveta, and Sidney Tarrow. 2007. "Transactional and Participatory Activism in the Emerging European Polity: The Puzzle of East-Central Europe.” Comparative Political Studies vol. 40, no.1: 74-94.

Roberts, Adrienne. 2015. "The Political Economy of »Transnational Business Feminism«. Problematizing the Corporate-Led Gender Equality Ahenda." International Feminist Journal of Politics vol. 17, no. 2: 209-231. https://doi.org/10.1080/14616742.2013.849968

Roth, Silke. 2007. "Sisterhood and Solidarity? Women's Organizations in the Expanded European Union.” Social Politics vol. 14, no. 4: 460-487. https://doi.org/10.1093/sp/jxm019

Roy, Srila. 2017. "The Positive Side of Co-Optation? Intersectionality: A Conversation Between Inderpal Grewal and Srila Roy." International Feminist Journal of Politics vol. 19, no. 2: 254-262. https://doi.org/10.1080/14616742.2017.1291225

Selznick, Philip. 1949. TV A and the Grass Roots: A Study in the Sociology of Formal Organization. Berkeley-Los Angeles: University of California Press.

Stratigaki, Maria. 2004. "The Cooptation of Gender Concepts in EU Policies: The Case of »Reconciliation of Work and Family«." Social Politics: International Studies in Gender, State \& Society vol. 11, no. 1: 30-56. https://doi.org/10.1093/sp/jxh025

Vlad, Ioana. 2013. Women's Rights Activism in Romania After 2000. Studies on the Forms of Organization, Cooperation, Action and Influence. [Doctoral thesis].

Vlad, Ioana. 2015. "Dezvoltari in miscarea de femei dupa 2000.” In Mișcări feministe și ecologiste in România (1990-2014). Ed. Mihaela Miroiu. Iasi: Polirom. 
Alexandra Ana - a PhD candidate in Political Science and Sociology at Scuola Normale Superiore, in Florence, with a thesis on comparative feminist movements, under the supervision of Donatella della Porta. Her current research interests include gender and sexuality, social movements, particularly the right to housing movement and the feminist movement, labor precarity and migration. She is currently teaching sociology, with a focus on gender and urban sociology at Sciences Po. Her last article analyses 'The Role of the Feminist Movement Participation during the Winter 2012 Mobilizations in Romania' (2017) was published in Europe-Asia Studies.

\section{ADDRESS:}

Alexandra Ana, PhD Candidate

Scuola Normale Superiore

Institute for Humanities and Social Sciences

Palazzo Strozzi, Piazza Strozzi

50123 Florence - Italy

EMAIL: alexandra.ana@sns.it

Citation: Ana, Alexandra. 2018. "Precarious Locations: Feminist Co-optation and Strategies of Resistance in the Neoliberal Age" Praktyka Teoretyczna 4(30): 153-179.

DOI: $10.14746 /$ prt.2018.4.6

\section{AUTOR: Alexandra Ana}

TYTUŁ: Niepewne miejsca: feministyczna kooptacja i strategie oporu w czasach neoliberalizmu?

ABSTRAKT: Gdy kobiety zyskały możliwość wpływania na politykę za pośrednictwem oficjalnych kanałów, postulaty feministek dotyczące sprawiedliwości społecznej zaczęto realizować w Rumunii poprzez zinstytucjonalizowane formy interwencji politycznej. Instytucjonalizację i profesjonalizację ruchu feministycznego powszechnie kojarzono z feministycznymi i kobiecymi organizacjami pozarządowymi współpracującymi z rządowymi organami do spraw równości płci w celu realizacji postulatów ruchu i osiagnięcia sukcesu w sferze polityki. Podczas gdy niektórzy badacze zawracali uwage na korzyści płynące z przenikania idei i praktyk feministycznych do struktury państwa, inni uważali, że organizacje pozarządowe czynią ruch feministyczny podatnym na kooptację, przyczyniając się do jego demobilizacji i odpolitycznienia. Koncepcja kooptacji odzwierciedla dylematy, przed którymi stoją współczesne ruchy feministyczne. Dylematy te dotyczą przesuwania celów ruchu, które mogą być dostosowane do innych priorytetów i programów - czasami działając na niekorzyść 
ruchu i w sprzeczności z pierwotnymi celami, szczególnie gdy staną się częścią oficjalnych kanałów politycznych. Zależność feministycznych grup i organizacji pozarządowych od funduszy państwowych lub prywatnych jest również powiązana z kooptacją ruchu. Jak budować ruch na krytycznych analizach koncepcji kooptacji bez jednoczesnego kwestionowania wagi działań i wysiłków aktywistów feministycznych i organizacji pozarządowych jako legitymizujących programy polityczne państwowych lub prywatnych darczyńców? Badanie to ma na celu, po pierwsze, wyjaśnienie napięć powstałych w wyniku kooptacji i związanych z dylematem bycia wewnątrz/na zewnątrz, przed którym stoi współczesny ruch feministyczny. Po drugie, celem autorki artykułu jest zbadanie strategii przeciwstawienia się lub zarządzania kooptacja opracowanych przez ruch feministyczny. Do analizy procesu kooptacji, a zwłaszcza wywoływanych przez ów proces napięć i powstałych wopozycji do niego strategii oporu, w tekście wykorzystano literaturę NGO-izacji i przedstawiono empiryczne dowody pochodzące $z$ badań nad rumuńskim ruchem feministycznym.

SŁOWA KLUCZOWE: kooptacja, instytucjonalizacja, NGO-izacja, ruch feministyczny, zależność finansowa 